\title{
New mechanisms of normoxic and hypoxic cGMP signalling mediated by the nitrite anion
}

\author{
Hunter Champion \\ From 6th International Conference on cGMP: Generators, Effectors and Therapeutic Implications \\ Erfurt, Germany. 28-30 June 2013
}

\begin{abstract}
Backgound
Chronic treatment with sodium nitrite has been shown to be efficacious in preclinical models of pulmonary arterial hypertension $(\mathrm{PAH})$. The present study was designed to test the acute hemodynamic effects and safety of inhaled nitrite in patients with PAH (treatment naïve or on background therapy). Details: http://www.clinicaltrials.gov NCT01431313 METHODS: Inhaled nitrite was delivered at incremental doses (45 and $90 \mathrm{mg}$ ) to WHO group I and WHO Group III PAH patients undergoing clinical right heart catheterization for the diagnosis or management of PAH. In addition to clinical measures of safety and treatment response, novel hemodynamic parameters of RV function were acquired by both micromanometry and echocardiography.
\end{abstract}

\section{Results}

Inhaled nitrite was well tolerated by all subjects $(n=10)$ at both the $45 \mathrm{mg}$ and 90 doses in treatment naïve and patients on background therapy (mean systemic blood pressure and systemic vascular resistance were not altered at either dose (NS; $P>0.05$ ) including patients on background PDE5A inhibitor therapy $(\mathrm{n}=8)$. Inhaled nitrite lowered mean pulmonary arterial pressure (mPAP) and pulmonary vascular resistance (PVR) in a dose-dependent manner. Inhaled nitrite $45 \mathrm{mg}$ and $90 \mathrm{mg}$ doses lowered mPAP by $9.6 \pm 0.6 \%$ and $12.4 \pm 2.2(P<0.0001)$ and PVR by $12.4 \pm 5.3 \%$ and $19.3 \pm 5.3 \%(P=0.006)$, respectively. Interestingly, inhaled nitrite resulted in a marked lowering of right atrial pressure $(P<0.001)$ and pulmonary capillary wedge pressure $(P<0.001)$. When coupled with the observation of improvements in $\mathrm{dP} / \mathrm{dt}_{\mathrm{min}}$, these data suggest that inhaled nitrite may exert a novel lusitropic ventricular effect. Nitrite inhalation resulted in a significant increase in plasma cGMP concentrations.

Correspondence: championhc@upmc.edu

University of Pittsburgh, Pittsburgh, PA 15213, USA

\section{Conclusion}

This preliminary analysis of an open-label study of inhaled nitrite in patients with PAH provide evidence for tolerability of the drug in treatment naïve and patients on background therapy (including PDE5A inhibitors). Moreover, these data demonstrate that inhaled nitrite induces a dose-dependent reduction in MPAP and PVR in patients with PAH.

Published: 29 August 2013

doi:10.1186/2050-6511-14-S1-O20

Cite this article as: Champion: New mechanisms of normoxic and

hypoxic CGMP signalling mediated by the nitrite anion. BMC

Pharmacology and Toxicology 2013 14(Suppl 1):O20.

Submit your next manuscript to BioMed Central and take full advantage of:

- Convenient online submission

- Thorough peer review

- No space constraints or color figure charges

- Immediate publication on acceptance

- Inclusion in PubMed, CAS, Scopus and Google Scholar

- Research which is freely available for redistribution
C Biomed Central

C 2013 Champion; licensee BioMed Central Ltd. This is an Open Access article distributed under the terms of the Creative Commons Attribution License (http://creativecommons.org/licenses/by/2.0), which permits unrestricted use, distribution, and reproduction in any medium, provided the original work is properly cited. 